Delft University of Technology

\title{
The Longitudinal Profile of a Prograding River and Its Response to Sea Level Rise
}

Gao, Weilun; Li, Dongxue; Wang, Zhengbing ; Nardin, William; Shao, Dongdong; Sun, Tao; University, Beijing; Cui, Baoshan

DOI

10.1029/2020GL090450

Publication date

2020

Document Version

Final published version

Published in

Geophysical Research Letters

\section{Citation (APA)}

Gao, W., Li, D., Wang, Z., Nardin, W., Shao, D., Sun, T., University, B., \& Cui, B. (2020). The Longitudinal Profile of a Prograding River and Its Response to Sea Level Rise. Geophysical Research Letters, 47(21), 1 9. [e2020GL090450]. https://doi.org/10.1029/2020GL090450

\section{Important note}

To cite this publication, please use the final published version (if applicable).

Please check the document version above. 


\section{Geophysical Research Letters}

\section{RESEARCH LETTER \\ 10.1029/2020GL090450 \\ Key Points: \\ - A theoretical framework is proposed for predicting the evolution of the longitudinal profile and its concavity of prograding rivers \\ - Numerical results suggest a critical ratio of accommodation space to sediment supply for the formation of a concave profile \\ - Sea level rise tends to increase the concavity of river profiles with a relatively low bed slope and progradation rate}

Supporting Information:

- Supporting Information S1

Correspondence to: D. Shao and B. Cui, ddshao@bnu.edu.cn; cuibs@bnu.edu.cn

Citation:

Gao, W., Li, D., Wang, Z. B., Nardin, W., Shao, D., Sun, T., et al. (2020). The longitudinal profile of a prograding river and its response to sea level rise. Geophysical Research Letters, 47, e2020GL090450. https://doi.org/ 10.1029/2020GL090450

Received 20 AUG 2020 Accepted 19 OCT 2020 Accepted article online 21 OCT 2020

\section{The Longitudinal Profile of a Prograding River and Its Response to Sea Level Rise}

\author{
Weilun Gao ${ }^{1,2,3} \mathbb{D}$, Dongxue $\mathrm{Li}^{1,3}$, Zheng Bing Wang ${ }^{1,4,5} \mathbb{D}$, William Nardin ${ }^{6}(\mathbb{D}$, \\ Dongdong Shao ${ }^{1,3,7}\left(\mathbb{D}\right.$, Tao Sun $^{1,3}$ (D), Chiyuan Miao ${ }^{8}$ iD, and Baoshan $\mathrm{Cui}^{1,3}$ \\ ${ }^{1}$ State Key Laboratory of Water Environment Simulation and School of Environment, Beijing Normal University, Beijing, \\ China, ${ }^{2}$ Research and Development Center for Watershed Environmental Eco-Engineering, Beijing Normal University, \\ Zhuhai, China, ${ }^{3}$ Yellow River Estuary Wetland Ecosystem Observation and Research Station, Ministry of Education, \\ Shandong, China, ${ }^{4}$ Deltares, Delft, Netherlands, ${ }^{5}$ Faculty of Civil Engineering and Geosciences, Delft University of \\ Technology, Delft, Netherlands, ${ }^{6}$ Horn Point Laboratory, University of Maryland Center for Environmental Science, \\ Cambridge, MD, USA, ${ }^{7}$ Tang Scholar, Beijing Normal University, Beijing, China, ${ }^{8}$ State Key Laboratory of Earth Surface \\ Processes and Resource Ecology, Faculty of Geographical Science, Beijing Normal University, Beijing, China
}

\begin{abstract}
River longitudinal profile, a key morphological characteristic of the river channel, is subject to river mouth progradation. Given the increasing influence of human activities and climate change on this critical downstream control, understanding its effects on the evolution of the longitudinal profile is imperative. A general theoretical framework is proposed to quantify the relevant effects, which is tested by numerical experiment and compared with field, numerical and laboratory data from the literature. The results suggest the existence of a critical ratio of accommodation space to sediment supply of approximately 0.5 , above which the typical concave upward profile tends to form. Further analyses show that sea level rise tends to increase the concavity of the longitudinal profile of a river with a relatively low equilibrium bed slope and progradation rate.
\end{abstract}

Plain Language Summary As a key feature of a river, the bed level along the river, i.e., the river longitudinal profile, affects flooding, navigation, etc., and thus greatly influences human societies and natural ecosystems. However, the effects of the seaward progradation of a river mouth on the evolution of the river longitudinal profile are still unclear. Given the increasing influence of human activities and climate change on this critical downstream control, understanding these effects becomes imperative. A new theoretical framework incorporating the effects of river mouth progradation on the evolution of a river longitudinal profile is developed and tested by numerical experiments, field observations, and numerical and laboratory data from the literature. The results show that the seaward progradation of a river mouth could potentially lead to the formation of a concave river longitudinal profile. Specifically, we found that there exists a critical condition in which the sediment supply is insufficient to balance the seaward progradation of the river mouth, causing the typical concave upward longitudinal profile to form. The proposed theoretical framework further suggests that sea level rise tends to increase the concavity of the longitudinal profile for river with a relatively low equilibrium bed slope and progradation rate.

\section{Introduction}

The morphological evolution of river channels affects river flooding and navigation and thus plays a vital role in both human society and fluvial ecosystems (Best, 2019; Stähly et al., 2019; Wohl et al., 2015). As one of the key morphological characteristics of a river channel, the curvature of its longitudinal profile influences important processes, such as channel avulsion (Chadwick et al., 2019) and sediment delivery in deltaic systems (Bijkerk et al., 2016), and therefore has been extensively studied (Blom et al., 2016; Bolla Pittaluga et al., 2014; Ferrer-Boix et al., 2016). It is well known that the evolution of a river longitudinal profile is subject to both upstream boundary conditions, including river discharge and sediment load (Blom et al., 2017; Bolla Pittaluga et al., 2014; Chatanantavet et al., 2012; Fasolato et al., 2009; Zaprowski et al., 2005), and downstream controls, including river mouth progradation and sea level rise (Blum \& Törnqvist, 2000; Fagherazzi et al., 2015; Muto \& Swenson, 2005; Swenson, 2005; Wu et al., 2020). Given the increasing intervention of human activities and climate change in the progradation of river mouths (Besset et al., 2019;
(C)2020. American Geophysical Union. All Rights Reserved. 

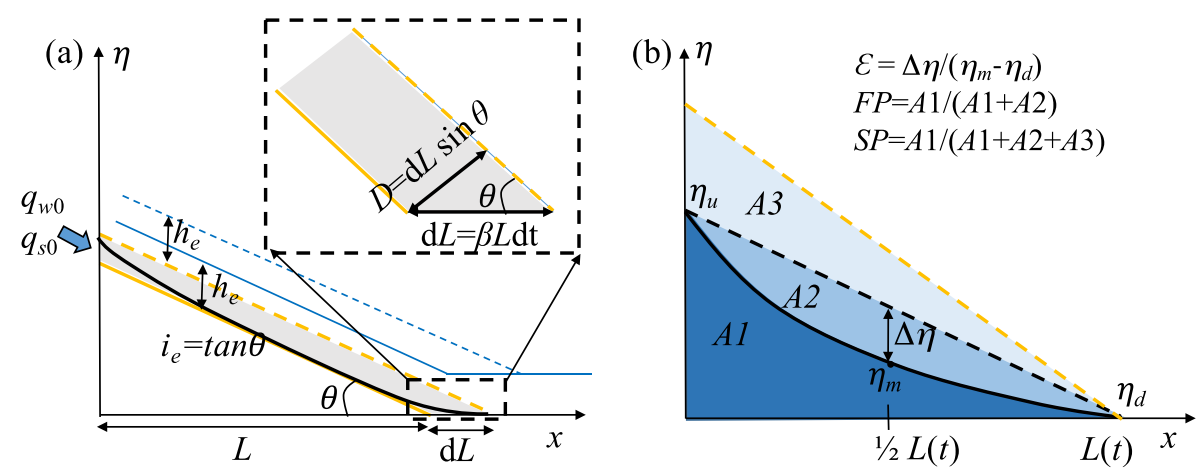

Figure 1. (a) Schematic of the evolution of a river profile under the progradation of the river mouth. (b) Schematic of the normalized bed difference, $\varepsilon$, proposed in this study, as well as the fill percentage, $F P$, and slope percentage, $S P$, of the river profile proposed by Bijkerk et al. (2016).

Gao et al., 2019), understanding its effects on the evolution of rivers, particularly the change in the longitudinal profile curvature, becomes imperative.

The intrinsic characteristic of a river channel is to evolve toward an equilibrium longitudinal profile, i.e., one with an equilibrium bed slope that allows the river channel to transport exactly the sediment load supplied from the upstream (Chang, 1986; Jansen et al., 1979; Mackin, 1948; Nones et al., 2019). The equilibrium longitudinal profile typically exhibits a concave form in reality, which could result from various mechanisms causing the downstream decrease in the equilibrium bed slope, such as downstream fining due to abrasion and selective transport of sediment (e.g., Blom et al., 2016; Paola et al., 1992b), tributary (e.g., Sinha \& Parker, 1996), and variation in channel width (e.g., Ferrer-Boix et al., 2016; Li et al., 2014). Dating back to Mackin's (1948) definition on the grade profile (i.e., the equilibrium profile), previous studies including those mentioned above focused primarily on the concavity of the river profile at its equilibrium state, which explicitly or implicitly assumed that the river profile can eventually attain an equilibrium profile (Muto \& Swenson, 2005; Nones et al., 2019).

However, when downstream controls are considered, river mouth progradation and sea level rise will lead to the continuous aggradation of the riverbed to approach a new equilibrium profile and thus maintain the sediment transport capacity (Muto \& Swenson, 2005; Schumm, 1993; Wang et al., 2019). In such cases, the assumption of attaining an equilibrium profile may not hold for the lower river section, as suggested by some previous experimental and numerical studies (Muto \& Swenson, 2005; Sinha \& Parker, 1996; Wu $\&$ Nittrouer, 2020) that river mouth progradation and sea level rise could prevent river profile from attaining the equilibrium profile, and instead a concave profile (Figure 1a) forms as a transient state (Chang, 1986; Muto \& Swenson, 2005; Nones et al., 2019). Although the nearshore water depth and the progradation rate of the river mouth are considered the first-order controls on the attainment of the equilibrium river profile (Bijkerk et al., 2016; Wang et al., 2019; Wu \& Nittrouer, 2020), its actual development essentially depends on the infilling of the accommodation space between the initial and equilibrium profiles (i.e., the "progradation-induced accommodation space" in this study). The infilling of the accommodation space is further dictated by the interplay between the sediment supply and the generation of accommodation space (Coe et al., 2003; Di Silvio \& Nones, 2014; Muto \& Steel, 1997), the processes of which still remains largely unclear.

To address this gap, a general theoretical framework is proposed in this study to investigate when and how river mouth progradation can keep the river channel from attaining an equilibrium profile and therefore result in a transient concave profile (section 2). We further test the framework using numerical experiments (sections 3, 4.1, and 4.2) as well as field, numerical, and laboratory data from the literature (section 4.3). Further applications of the theoretical framework to analyze the potential impacts of sea level rise and longitudinally increasing river discharge mimicking the lateral water input from hillslopes, ground water, and tributaries are also discussed (sections 4.4 and 4.5).

\section{Theoretical Framework}

To derive a theoretical framework for analyzing the evolution of a longitudinal profile under river mouth progradation, we only include the essential physical processes for simplicity (Paola \& Leeder, 2011). 
We consider a lower reach of the river without tributaries where the river width is fixed and downstream fining is negligible, as commonly assumed in previous studies (An et al., 2018; Chadwick et al., 2020; Moodie et al., 2019), which results in a quasilinear profile for the equilibrium form (Figure 1a). However, these assumptions can be relaxed, and analysis incorporating other coexisting factors can be performed using the same theoretical framework as demonstrated in an example in section 4.5. As shown in Figure 1a, an initial river profile (solid yellow line) in an equilibrium form tends to evolve toward a new equilibrium profile (dashed yellow line) due to the progradation of the river mouth, which allows the river channel to remain the sediment transport capacity (Muto \& Swenson, 2005; Schumm, 1993). As such, a progradation-induced accommodation space between the initial and new equilibrium profiles (the shaded area in Figure 1a), i.e., a nonmarine accommodation space, is created (Di Silvio \& Nones, 2014; Muto \& Steel, 2000; Posamentier \& Vail, 1988; Schumm, 1993), which is to be filled to attain the new equilibrium profile depending on how much sediment deposits in the river channel (Di Silvio \& Nones, 2014). The infilling of the accommodation space therefore can be quantified by a ratio of the accommodation space to the potential maximum river channel deposit volume in the nondimensional form, which is typically called the $A / S$ ratio (Coe et al., 2003; Huerta et al., 2011; Muto \& Steel, 1997; Nichols, 1989).

As shown in Figure 1a, the accommodation space per unit width $A$ can be written as

$$
A=\frac{1}{2} \cdot \frac{2 L+\mathrm{d} L}{\cos \theta} \cdot \mathrm{d} L \cdot \sin \theta
$$

where $L(\mathrm{~m})$ is the characteristic river length and $\theta$ is the angle between the equilibrium riverbed and the horizontal plane. The expansion of Equation 1 and omission of the second-order infinitesimal term lead to

$$
A=\beta L^{2} i_{e} \mathrm{~d} t
$$

where $\beta=(\mathrm{d} L / \mathrm{d} t) / L\left(\mathrm{~s}^{-1}\right)$ is the progradation rate of the river mouth normalized by $L, t(\mathrm{~s})$ is time, and $i_{e}=\tan \theta$ is the equilibrium bed slope (see Wang et al., 2008, for a detailed derivation).

The potential maximum river channel deposit volume per unit width, $V_{s}$, equals the sediment supplied at the upstream boundary:

$$
V_{s}=I_{f} \cdot \frac{q_{s 0}}{1-\lambda} \mathrm{d} t
$$

where $q_{s 0}\left(\mathrm{~m}^{2} / \mathrm{s}\right)$ is the specific sediment load at the upstream boundary, $\lambda$ is porosity, and $I_{f}$ is the flood intermittency factor (Miller et al., 2019). The $A / S$ ratio thus can be written as

$$
A / S=\frac{A}{V_{S}}=\frac{(1-\lambda) \cdot \beta L^{2} i_{e}}{I_{f} \cdot q_{s 0}}
$$

Therefore, we hypothesize that the river profile could attain a new quasilinear equilibrium profile in this study when the river channel deposits are likely to fill the accommodation space, i.e., $A / S \leq 1$, such as the lower reach of the Yellow River in China, which is subject to high fluvial sediment input and fast prograding (see section 4.3). Otherwise, the river channel cannot obtain the equilibrium profile due to the shortage of sediment required to infill the accommodation space, resulting in a concave profile in this study, such as the Patuka River in Honduras, which is subject to limited fluvial sediment load and yet exhibits significant progradation rate due to alongshore sediment load (Nienhuis et al., 2016).

In this study, the normalized bed difference, $\varepsilon=\Delta \eta /\left(\eta_{m}-\eta_{d}\right)$, was proposed as a proxy to quantify the concavity of the river profile (Figure 1b). The bed level difference between the equilibrium (quasilinear) profile and the evolving concave profile at the midpoint of the river length $\Delta \eta$ is equal to $\left(\eta_{u}+\eta_{d}\right) / 2-\eta_{m}$, where $\eta_{u}, \eta_{m}$, and $\eta_{d}$ are the bed levels at the upstream boundary, the midpoint of the river length, and the downstream boundary, respectively. The fill percentage $(F P)$ and slope percentage $(S P)$ of the river profile proposed by Bijkerk et al. (2016) were also calculated in this study (Figure 1b). Following Bijkerk et al. (2016), $F P=A 1 /(A 1+A 2)$ and $S P=A 1 /(A 1+A 2+A 3)$, where $A 1$ is the area between the horizontal plane at the river mouth and the concave profile, $A 2$ is the area between the concave profile and the average profile 
(dashed black line in Figure 1b), and $A 3$ is the area between the average profile and the new equilibrium profile. Given the definitions provided in this study, the concavity of the river profile increases with increasing $\varepsilon$ and decreasing FP and SP. When $\varepsilon$ equals zero and FP and $S P$ equal unity, the river profile attains an equilibrium (quasilinear) form.

\section{Development of Numerical Model}

\subsection{Governing Equations}

A 1-D numerical model, which incorporates the 1-D steady Saint-Venant equations (Chow, 1959), general power law for the sediment transport capacity (Jansen et al., 1979), and Exner equation for the evolution of the channel bed level (Paola et al., 1992a; Paola \& Voller, 2005), was developed to simulate the evolution of a river profile and test the generic hypothesis derived from the theoretical framework. The governing equations are documented in the supporting information.

\subsection{Boundary Conditions}

A constant specific bank-full discharge, $q_{w 0}$, and specific sediment load, $q_{s 0}$, were imposed at the upstream boundary, whereas a constant water level $(H=0 \mathrm{~m})$ and progradation rate of the river mouth were prescribed at the downstream boundary:

$$
\begin{gathered}
q_{w}(x=0, t)=q_{w 0} \\
q_{s}(x=0, t)=q_{s 0} \\
H(x=L(t), t)=0 \\
L(t)=L_{0} \cdot(1+\beta \cdot t)
\end{gathered}
$$

Note that the river mouth progradation rate could be proportional to the sediment discharge (Aadland \& Helland-Hansen, 2019); however, the dependency can be mediated by nearshore water depth, baselevel changes, waves, etc. (Bijkerk et al., 2016; Gao et al., 2020; Swenson et al., 2005; Wang et al., 2019; Wu et al., 2020; Wu \& Nittrouer, 2020). In deflected river mouths under waves, the progradation rate can be insensitive to fluvial sediment load but more dependent on alongshore sediment load (Gao et al., 2020; Nienhuis et al., 2016). Since we did not associate our framework with any specific receiving basins with a given nearshore water depth, baselevel changes, wave conditions, etc., we imposed a boundary condition of progradation rate at the river mouth as appropriate alongside the upstream sediment supply (Equation 8) to focus on the evolution of the longitudinal profile as the main target of our study.

\subsection{Parameter Space}

The initial river length $\left(L_{0}\right)$ was set to $150-300 \mathrm{~km}$, which was also adopted as the characteristic river length in this study. The initial riverbed was linear with the equilibrium slope, $i_{e}$. The commonly used sediment transport formulas, e.g., the Engelund-Hansen formula (Engelund \& Hansen, 1967), Meyer-Peter and Müller formula (with a critical shear stress) (Meyer-Peter \& Müller, 1948), Einstein-Brown formula (Brown, 1950), and more recently the Generalized Engelund-Hansen formula (Ma et al., 2017; Ma et al., 2020), can be well represented by the power law relationship in Equation S4 in the supporting information by changing the coefficients $m\left(\mathrm{~s}^{n-1} / \mathrm{m}^{n-2}\right)$ and $n$. In this study, we employed the Engelund-Hansen formula for total sediment transport (Engelund \& Hansen, 1967), i.e., $m=\frac{0.05 C_{f}^{1.5}}{(R g)^{2} D_{50}}$ and $n=5$, where $R(=1.65)$ is the submerged specific gravity of the sediment. The other modeling parameters were set as follows: bed porosity $\lambda=0.4$, flood intermittency factor $I_{f}=0.1-0.2$, and nondimensional friction coefficient $C_{f}=0.0011$ following An et al. (2018).

Simulation scenarios were conducted with different combinations of specific river discharges $\left(q_{w 0}\right.$, $\left.0.2-25 \mathrm{~m}^{2} / \mathrm{s}\right)$, sediment load $\left(q_{\mathrm{s} 0}, 7.55 \times 10^{-6}\right.$ to $\left.9.43 \times 10^{-3} \mathrm{~m}^{2} / \mathrm{s}\right)$, sediment grain sizes $\left(D_{50}, 0.065-0.2 \mathrm{~mm}\right)$, and river mouth progradation rates $\left(\beta L_{0}, 0-2,000 \mathrm{~m} / \mathrm{yr}\right)$. To make the results of the simulation scenarios with different progradation rates $\left(\beta L_{0}\right)$ comparable, the simulation periods $\left(t=\Delta L / \beta L_{0}\right)$ were varied accordingly (from 12.5 to $1,000 \mathrm{yr}$ ) to maintain the same total progradation distance $(\Delta L)$ among the different 

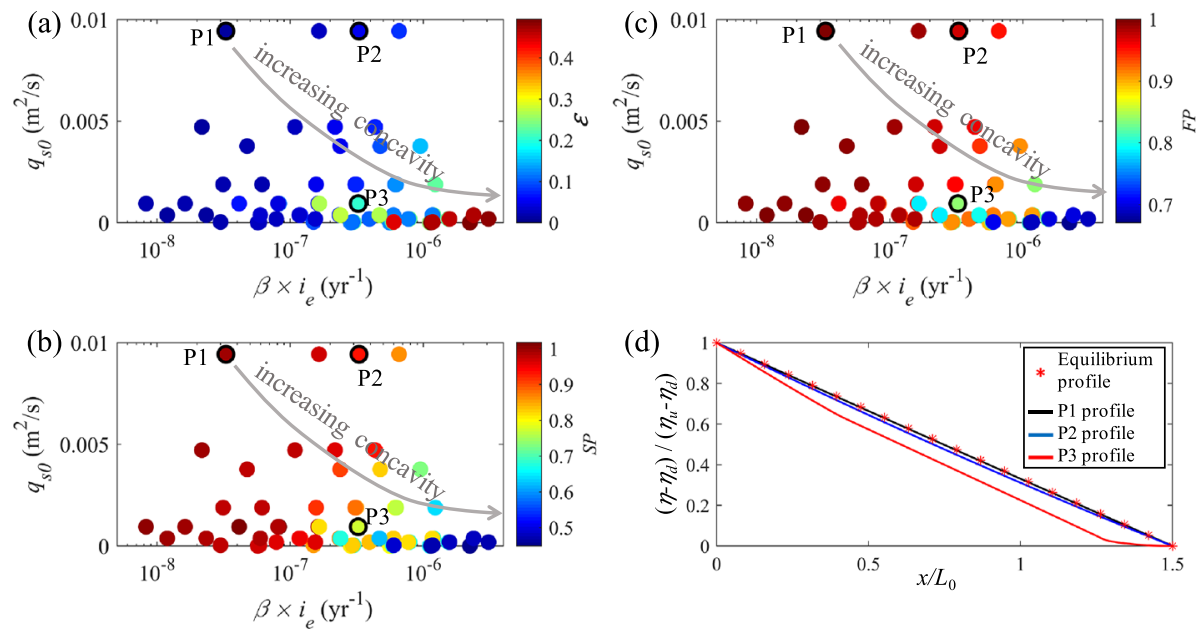

Figure 2. Concavity indices, including (a) the normalized bed difference, $\varepsilon$; (b) the fill percentage of the longitudinal profile, FP; and (c) the slope percentage of the longitudinal profile, $S P$, as a function of the product of normalized progradation rate and equilibrium bed slope $\beta \times i_{e}$ and sediment supply $q_{s 0}$. (d) Corresponding river profiles for the black-edged symbols in (a)-(c). The initial river length is $L_{0}=200 \mathrm{~km}$, the flood intermittency factor is $I_{f}=0.1$, and the total progradation distance is $\Delta L=100 \mathrm{~km}$.

scenarios. The ranges of the specific river discharge, sediment load, and sediment grain size are representative of global rivers (Syvitski \& Saito, 2007), whereas the river mouth progradation rate corresponds to one of the world's fastest prograding rivers, the Yellow River in China (Wang \& Liang, 2000). Sensitivity analyses (supporting information) show that the selections of the modeling parameters and sediment transport formula (i.e., the general Meyer-Peter and Müller formula) do not change the conclusions in this study. The requirements of a sufficiently small time step and grid size were tested as well (see Figure S1).

\section{Results and Discussion}

\subsection{Evolution of River Longitudinal Profiles Under the Progradation of the River Mouth}

The numerical results show that the concavity indices (i.e., $\varepsilon, F P$, and $S P$ defined in Figure $1 \mathrm{~b}$ ) tend to increase with increasing product of normalized progradation rate and equilibrium bed slope $\beta \times i_{e}$ and decreasing sediment supply $q_{s 0}$ (Figures $2 \mathrm{a}-2 \mathrm{c}$ ), which represent an increasing progradation-induced accommodation space and a decreasing maximum river channel deposit volume, respectively. Specifically, when the river channel deposition is capable of continuously filling the progradation-induced accommodation space, the river profile could remain in equilibrium (profile P1 in Figure 2d), whereas a concave profile emerges when the deposits cannot fill the increasing accommodation space (profile P2 in Figure 2d). Alternatively, a prominent concave profile forms due to relatively low river channel deposition and relatively high accommodation space formation (profile P3 in Figure 2d).

The numerical results confirm that the progradation of a river mouth could lead to the formation of a concave river profile (Bijkerk et al., 2016; Muto \& Swenson, 2005). Our results further suggest that in addition to the progradation rate of the river mouth, the concavity of the river profile also depends on its equilibrium bed slope $\left(i_{e}\right)$ and sediment load at the upstream boundary $\left(q_{s 0}\right)$. As such, the interplay between the progradation-induced accommodation space and sediment supply (Equation 4), i.e., the $A / S$ ratio, is among the main controls on the evolution of the river profile.

\subsection{Relationship Between Concavity and $A / S$ Ratio}

The relationships between the concavity indices of the river profile and the $A / S$ ratio is shown in Figure 3 . Consistent with the generic hypothesis derived from the theoretical framework, when the $A / S$ ratio is relatively small ( $<0.5), \varepsilon$ is close to 0 and $F P$ and $S P$ are close to 1 . With an increasing $A / S$ ratio, the river channel deposits cannot continue to fill the accommodation space (i.e., $V_{S}<A$ ), which results in a concave profile with increasing $\varepsilon$ and decreasing $F P$ and $S P$. In addition, the numerical experiments suggest the existence 

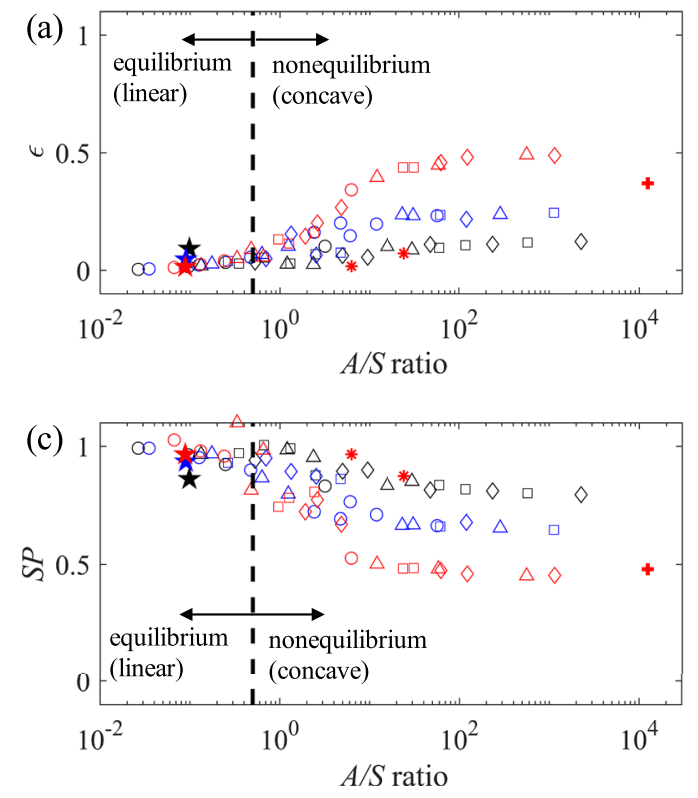
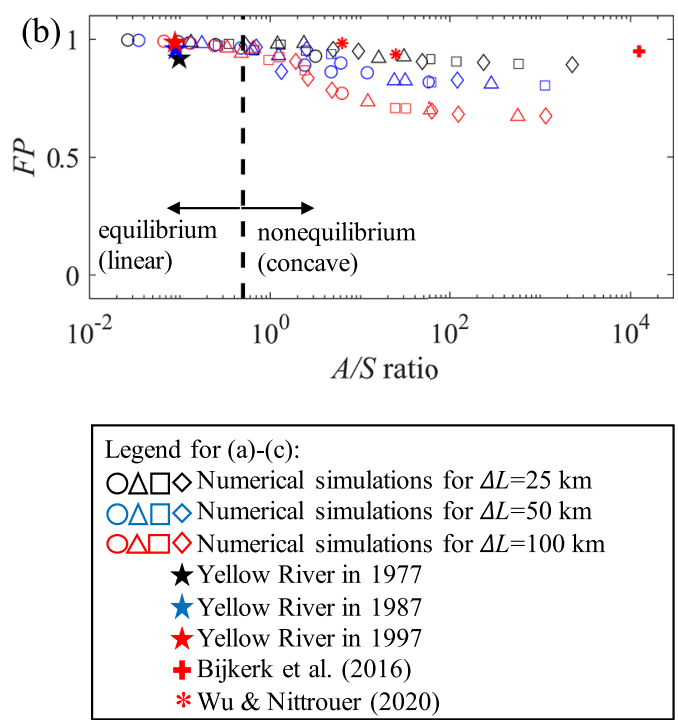

Figure 3. Relationship between the $A / S$ ratio and (a) the normalized bed difference, $\varepsilon$; (b) the fill percentage of the river profile, FP; and (c) the slope percentage of the river profile, $S P$, for representative numerical experiments, the lower reach of the Yellow River, the physical experiments in Bijkerk et al. (2016), and the numerical results from Wu and Nittrouer (2020). The hollow circles, triangles, rectangles, and diamonds represent numerical scenarios with different normalized progradation rates $\beta$ of $0.0005,0.0025,0.005$, and $0.01 \mathrm{yr}^{-1}$, respectively.

of a critical $A / S$ ratio of $\sim 0.5$ (Figure 3), above which a concave profile tends to form. Moreover, the concavity further increases with the total progradation distance $\Delta L$ when a concave profile forms, which is consistent with the results of Wu and Nittrouer (2020) and suggests a long-term cumulative effect on the evolution of the concavity, i.e., concavity increases as time elapses.

\subsection{Comparison With Field, Numerical, and Laboratory Data}

The generic hypothesis derived from the theoretical framework and numerical experiments are further compared with field, numerical, and laboratory data from the literature (see supporting information for details). For the lower reach of the Yellow River downstream of Taochengpu (Figure S4) (Wang et al., 2008; Zheng et al., 2019), the high sediment load together with a bed slope of $1 \times 10^{-4}$ results in a low $A / S$ ratio, despite the relatively high progradation rate of the river mouth. As a result, the lower reach of the Yellow River approaches the equilibrium profile with a relatively low $\varepsilon$ and relatively high FP and $S P$ (the stars in Figure 3). Nevertheless, the longitudinal profile of the lower Yellow River would be a convex form due to water diversion, if not for river mouth progradation that plays the counteracting role to create the actual concave profile (Wang et al., 2008). In contrast, in the physical experiment conducted by Bijkerk et al. (2016), the relatively high equilibrium bed slope (0.01) and high progradation rate $(0.25 \mathrm{~m} / \mathrm{h})$ result in a high $A / S$ ratio (see Equation 4). Therefore, the river profile attains a relatively high $\varepsilon$ and relatively low $S P$, indicating a river profile away from an equilibrium (the crosses in Figure 3). Notably, the experiments of Bijkerk et al. (2016) used analogue models that were not hydrodynamically scaled to understand relevant processes. However, since our theoretical framework is zero dimensional as quantified by the $A / S$ ratio, it is capable of describing different kinds of flow regimes and morphological settings of the lower river reach, including the distorted physical models. The numerical results of Wu and Nittrouer (2020), though including sediment selective transport that could add to the concavity, show that greater progradation rate for a river emptying into a shallower receiving basin resulted in greater $A / S$ ratio and more concave profile, whereas smaller $A / S$ ratio and less concave profile would be attained for a river with smaller progradation rate when emptying into a deeper basin (the asterisks in Figure 3). Overall, the results from the literature are consistent with the generic hypothesis derived from our theoretical framework and numerical experiments. 

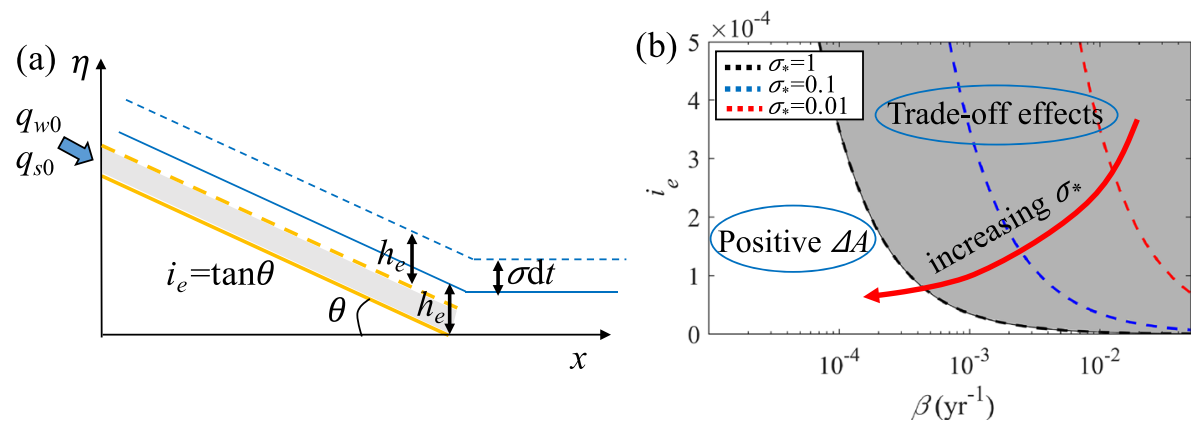

Figure 4. (a) Schematic of increasing accommodation space (shaded area) resulting from a rising sea level (from solid lines to dashed lines). The yellow lines are the bed level, the blue lines are the water surface, and $h_{e}(\mathrm{~m})$ is the equilibrium water depth. (b) Different regimes representing the net effects of sea level rise on the accommodation space in the parameter space of normalized progradation rate $\beta$ and equilibrium bed slope $i_{e}$ for a typical sea level rise rate $\sigma=7 \times 10^{-3} \mathrm{~m} / \mathrm{yr}$ and characteristic river length $L=200 \mathrm{~km}$. The black, blue, and red dashed lines represent the relationship between $\beta$ and $i_{e}$ for fixed given values of $\sigma *$

\subsection{Response of River Profile to Sea Level Rise}

Although sea level rise creates additional nonmarine accommodation space (Schumm, 1993) (Figure 4a), it also reduces progradation-induced accommodation space by increasing nearshore water depth and hence slowing down the progradation rate (Bijkerk et al., 2016; Chadwick et al., 2020; Muto \& Swenson, 2005; Wu \& Nittrouer, 2020). As such, based on our theoretical framework, sea level rise could have a trade-off effect on the evolution of a river profile (Equation 4). To further quantify the trade-off effect, the change in accommodation space $\Delta A$ under sea level rise (supporting information) can be written as

$$
\Delta A=A \cdot\left(\sigma_{*}-\beta_{*}\right)
$$

where $\sigma_{*}=\sigma /\left(\beta L_{0} i_{e}\right)$ is a dimensionless sea level rise rate, $\sigma(\mathrm{m} / \mathrm{s})$ is the sea level rise rate, $\beta_{*}=\left(1-\beta^{\prime} / \beta\right)$ is the dimensionless reduction in the normalized progradation rate, and $\beta^{\prime}\left(\mathrm{s}^{-1}\right)$ is the normalized progradation rate under sea level rise condition.

As shown in Figure 4b, the parameter space of the normalized progradation rate $\beta$ and equilibrium bed slope $i_{e}$ can be separated into two regimes by $\sigma_{*}=1$. Specifically, because $\beta_{*}<1$ (see the definition of $\beta_{*}$ ), $\Delta A$ is always positive when $\sigma_{*}>1$ : the regime with positive $\Delta A$. In such a case, the increase in accommodation space due to sea level rise prevails, leading to a more concave profile. When $\sigma_{*}<1$, the net effects of the sea level rise on the accommodation space depend on $\beta_{*}$ for a given $\sigma_{*}$ : the regime with trade-off effects. For example, when $\beta_{*}=0.1$ or 0.01 , the parameter space below the blue or red dashed line in Figure $4 \mathrm{~b}$ indicates a positive $\Delta A$ (Equation 9), respectively. Overall, sea level rise tends to increase the accommodation space for rivers with a relatively low equilibrium bed slope and progradation rate (see Figure $4 \mathrm{~b}$ and the definition of $\sigma_{*}$ ).

\subsection{Effects of the Downstream Increase of River Discharge on River Concavity}

When other coexisting factors such as the variations in river discharge, sediment load, channel width, grain size, etc. are considered, we show in additional scenarios incorporating longitudinally increasing river discharge (mimicking the lateral water input from hillslopes, ground water, and tributaries) that river mouth progradation can potentially add to the concavity resulted from longitudinally increasing river discharge (supporting information). The results suggest that downstream controls could act alongside the abovementioned factors in affecting river profile concavity. In such cases, the progradation-induced accommodation is the area between two concave river profiles formed due to the other factors (see Figure S7), and our framework predicts whether the river channel can maintain a concave equilibrium profile when subject to river mouth progradation (see Figures S8-S10).

\section{Conclusions}

In this study, the generic hypothesis derived from a newly developed theoretical framework, i.e., one that depends on the $A / S$ ratio, suggesting that the progradation of a river mouth could contribute to the 
formation of a concave river profile, is tested by numerical experiments and a comparison with field, numerical, and laboratory data from the literature. The numerical results show that the concavity of a river profile increases with increasing normalized progradation rate $\beta$ and equilibrium bed slope $i_{e}$ and decreasing sediment load $q_{s 0}$. The relationship between the concavity of the river profile and the $A / S$ ratio suggests the existence of a critical $A / S$ ratio of $\sim 0.5$. The river reach tends to attain an equilibrium or a concave upward profile when its $A / S$ ratio is below or above this threshold, respectively. Once a concave profile forms, the concavity tends to increase with increasing $A / S$ ratio and total progradation distance $\Delta L$. The proposed theoretical framework can also be applied to analyze the response of river profiles under future changes, such as a changing sea level, sediment supply, and land reclamation at coasts.

\section{Data Availability Statement}

The data are available online (https://zenodo.org/record/3380456\#.XWaxfi2VbeQ).

\section{Acknowledgments}

This work was supported by the Key Project of National Natural Science Foundation of China (grant 51639001), the Joint Funds of the National Natural Science Foundation of China (grant U1806217), and the Interdisciplinary Research Funds of Beijing Normal University. The financial support provided to $Z$. B. Wang from the State Administration of Foreign Experts Affairs of China (grants G20190001540 and GDW20161100287) is also grateful acknowledged. W. Gao is funded by the fellowship of China Postdoctoral Science Foundation (grant 2020M680438). Three anonymous reviewers provided helpful comments on an earlier draft of the manuscript.

\section{References}

Aadland, T., \& Helland-Hansen, W. (2019). Progradation rates measured at modern river outlets: A first-order constraint on the pace of deltaic deposition. Journal of Geophysical Research: Earth Surface, 124, 347-364. https://doi.org/10.1029/2018JF004750

An, C., Moodie, A. J., Ma, H., Fu, X., Zhang, Y., Naito, K., \& Parker, G. (2018). Morphodynamic model of the lower Yellow River: Flux or entrainment form for sediment mass conservation? Earth Surface Dynamics, 6(4), 989-1010. https://doi.org/10.5194/esurf-6-989-2018

Besset, M., Anthony, E. J., \& Bouchette, F. (2019). Multi-decadal variations in delta shorelines and their relationship to river sediment supply: An assessment and review. Earth-Science Reviews, 193, 199-219. https://doi.org/10.1016/j.earscirev.2019.04.018

Best, J. (2019). Anthropogenic stresses on the world's big rivers. Nature Geoscience, 12(1), 7-21. https://doi.org/10.1038/s41561-018-0262-x

Bijkerk, J. F., Eggenhuisen, J. T., Kane, I. A., Meijer, N., Waters, C. N., Wignall, P. B., \& McCaffrey, W. D. (2016). Fluvio-marine sediment partitioning as a function of basin water depth. Journal of Sedimentary Research, 86(3), 217-235. https://doi.org/10.2110/jsr.2016.9

Blom, A., Arkesteijn, L., Chavarrías, V., \& Viparelli, E. (2017). The equilibrium alluvial river under variable flow and its channel-forming discharge. Journal of Geophysical Research: Earth Surface, 122, 1924-1948. https://doi.org/10.1002/2017JF004213

Blom, A., Viparelli, E., \& Chavarrías, V. (2016). The graded alluvial river: Profile concavity and downstream fining. Geophysical Research Letters, 43, 6285-6293. https://doi.org/10.1002/2016GL068898

Blum, M. D., \& Törnqvist, T. E. (2000). Fluvial responses to climate and sea-level change: A review and look forward. Sedimentology, 47(s1), 2-48. https://doi.org/10.1046/j.1365-3091.2000.00008.x

Bolla Pittaluga, M., Luchi, R., \& Seminara, G. (2014). On the equilibrium profile of river beds. Journal of Geophysical Research: Earth Surface, 119, 317-332. https://doi.org/10.1002/2013JF002806

Brown, C. B. (1950). Sediment transportation. In H. Rouse (Ed.), Engineering hydraulics (pp. 769-857). New York: John Wiley and Sons.

Chadwick, A. J., Lamb, M. P., \& Ganti, V. (2020). Accelerated river avulsion frequency on lowland deltas due to sea-level rise. Proceedings of the National Academy of Sciences, 117(30), 17,584-17,590. https://doi.org/10.1073/pnas.1912351117

Chadwick, A. J., Lamb, M. P., Moodie, A. J., Parker, G., \& Nittrouer, J. A. (2019). Origin of a preferential avulsion node on lowland river deltas. Geophysical Research Letters, 46, 4267-4277. https://doi.org/10.1029/2019GL082491

Chang, H. H. (1986). River channel changes: Adjustments of equilibrium. Journal of Hydraulic Engineering, 112(1), 43-55. https://doi.org/ 10.1061/(ASCE)0733-9429(1986)112:1(43)

Chatanantavet, P., Lamb, M. P., \& Nittrouer, J. A. (2012). Backwater controls of avulsion location on deltas. Geophysical Research Letters, 39, L01402. https://doi.org/10.1029/2011GL050197

Chow, V. T. (1959). Open-channel hydraulics (Vol. 1). New York: McGraw-Hill.

Coe, A. L., Bosence, D. W. J., Church, K. D., Flint, S. S., Howell, J. A., \& Wilson, R. C. L. (2003). The sedimentary record of sea-level change. Cambridge, United Kingdom: Cambridge University Press.

Di Silvio, G., \& Nones, M. (2014). Morphodynamic reaction of a schematic river to sediment input changes: Analytical approaches. Geomorphology, 215, 74-82. https://doi.org/10.1016/j.geomorph.2013.05.021

Engelund, F., \& Hansen, E. (1967). A monograph on sediment transport in alluvial streams. Technical University of Denmark 0stervoldgade 10 , Copenhagen $\mathrm{K}$.

Fagherazzi, S., Edmonds, D., Nardin, W., Leonardi, N., Canestrelli, A., Falcini, F., et al. (2015). Dynamics of river mouth deposits. Reviews of Geophysics, 53, 642-672. https://doi.org/10.1002/2014RG000451

Fasolato, G., Ronco, P., \& Di Silvio, G. (2009). How fast and how far do variable boundary conditions affect river morphodynamics? Journal of Hydraulic Research, 47(3), 329-339. https://doi.org/10.1080/00221686.2009.9522004

Ferrer-Boix, C., Chartrand, S. M., Hassan, M. A., Martín-Vide, J. P., \& Parker, G. (2016). On how spatial variations of channel width influence river profile curvature. Geophysical Research Letters, 43, 6313-6323. https://doi.org/10.1002/2016GL069824

Gao, W., Nienhuis, J., Nardin, W., Wang, Z. B., Shao, D., Sun, T., \& Cui, B. (2020). Wave controls on deltaic shoreline-channel morphodynamics: Insights from a coupled model. Water Resources Research, 56, e2020WR027298. https://doi.org/10.1029/2020WR027298

Gao, W., Shao, D., Wang, Z. B., Nardin, W., Rajput, P., Yang, W., et al. (2019). Long-term cumulative effects of intra-annual variability of unsteady river discharge on the progradation of delta lobes: A modeling perspective. Journal of Geophysical Research: Earth Surface, 124, 960-973. https://doi.org/10.1029/2017JF004584

Huerta, P., Armenteros, I., \& Silva, P. G. (2011). Large-scale architecture in non-marine basins: The response to the interplay between accommodation space and sediment supply. Sedimentology, 58(7), 1716-1736. https://doi.org/10.1111/j.1365-3091.2011.01231.x

Jansen, P. P., Van Bendegom, L., Van den Berg, J., De Vries, M., \& Zanen, A. (1979). Principles of river engineering: The non-tidal alluvial river. London: Pitman.

Li, W., Wang, Z., Vriend, H. J. D., \& Maren, D. S. V. (2014). Long-term effects of water diversions on the longitudinal flow and bed profiles. Journal of Hydraulic Engineering, 140(6), 04014021. https://doi.org/10.1061/(ASCE)HY.1943-7900.0000856

Ma, H., Nittrouer, J. A., Naito, K., Fu, X., Zhang, Y., Moodie, A. J., et al. (2017). The exceptional sediment load of fine-grained dispersal systems: Example of the Yellow River, China. Science Advances, 3(5), e1603114. https://doi.org/10.1126/sciadv.1603114 
Ma, H., Nittrouer, J. A., Wu, B., Lamb, M. P., Zhang, Y., Mohrig, D., et al. (2020). Universal relation with regime transition for sediment transport in fine-grained rivers. Proceedings of the National Academy of Sciences, 117(1), 171-176. https://doi.org/10.1073/ pnas.1911225116

Mackin, H. J. (1948). Concept of the graded river. GSA Bulletin, 59(5), 463-512. 10.1130/0016-7606(1948)59[463:COTGR]2.0.co;2

Meyer-Peter, E., \& Müller, R. (1948). Formulas for bed-load transport. Paper presented at the 2nd Meeting of International Association for Hydraulic Research, Stockholm, Sweden.

Miller, K. L., Kim, W., \& McElroy, B. (2019). Laboratory investigation on effects of flood intermittency on fan delta dynamics. Journal of Geophysical Research: Earth Surface, 124, 383-399. https://doi.org/10.1029/2017JF004576

Moodie, A. J., Nittrouer, J. A., Ma, H., Carlson, B. N., Chadwick, A. J., Lamb, M. P., \& Parker, G. (2019). Modeling deltaic lobe-building cycles and channel avulsions for the Yellow River delta, China. Journal of Geophysical Research: Earth Surface, 12, 2438-2462. https:// doi.org/10.1029/2019JF005220

Muto, T., \& Steel, R. J. (1997). Principles of regression and transgression; the nature of the interplay between accommodation and sediment supply. Journal of Sedimentary Research, 67(6), 994-1000. https://doi.org/10.1306/d42686a8-2b26-11d7-8648000102c1865d

Muto, T., \& Steel, R. J. (2000). The accommodation concept in sequence stratigraphy: Some dimensional problems and possible redefinition. Sedimentary Geology, 130(1-2), 1-10. https://doi.org/10.1016/S0037-0738(99)00107-4

Muto, T., \& Swenson, J. B. (2005). Large-scale fluvial grade as a nonequilibrium state in linked depositional systems: Theory and experiment. Journal of Geophysical Research, 110, F03002. https://doi.org/10.1029/2005JF000284

Nichols, M. M. (1989). Sediment accumulation rates and relative sea-level rise in lagoons. Marine Geology, 88(3-4), 201-219. https://doi. org/10.1016/0025-3227(89)90098-4

Nienhuis, J. H., Ashton, A. D., Nardin, W., Fagherazzi, S., \& Giosan, L. (2016). Alongshore sediment bypassing as a control on river mouth morphodynamics. Journal of Geophysical Research: Earth Surface, 121, 664-683. https://doi.org/10.1002/2015JF003780

Nones, M., Varrani, A., Franzoia, M., \& Di Silvio, G. (2019). Assessing quasi-equilibrium fining and concavity of present rivers: A modelling approach. Catena, 181, 104073. https://doi.org/10.1016/j.catena.2019.104073

Paola, C., Heller, P. L., \& Angevine, C. L. (1992a). The large-scale dynamics of grain-size variation in alluvial basins, 1: Theory. Basin Research, 4(2), 73-90. https://doi.org/10.1111/j.1365-2117.1992.tb00145.x

Paola, C., \& Leeder, M. (2011). Simplicity versus complexity. Nature, 469(7328), 38-39. https://doi.org/10.1038/469038a

Paola, C., Parker, G., Seal, R., Sinha, S. K., Southard, J. B., \& Wilcock, P. R. (1992b). Downstream fining by selective deposition in a laboratory flume. Science, 258(5089), 1757-1760. https://doi.org/10.1126/science.258.5089.1757

Paola, C., \& Voller, V. R. (2005). A generalized Exner equation for sediment mass balance. Journal of Geophysical Research, 110 , F04014. https://doi.org/10.1029/2004JF000274

Posamentier, H. W., \& Vail, P. R. (1988). Eustatic controls on clastic deposition II-Sequence and systems tract models. In Sea-level changes: An integrated approach (Vol. 42, pp. 125-154). Broken Arrow, OK: SEPM Society for Sedimentary Geology. https://doi.org/10.2110/ pec.88.01.0125

Schumm, S. A. (1993). River response to baselevel change: Implications for sequence stratigraphy. The Journal of Geology, 101(2), 279-294. https://doi.org/10.1086/648221

Sinha, S. K., \& Parker, G. (1996). Causes of concavity in longitudinal profiles of rivers. Water Resources Research, 32(5), 1417-1428. https:// doi.org/10.1029/95WR03819

Stähly, S., Franca, M. J., Robinson, C. T., \& Schleiss, A. J. (2019). Sediment replenishment combined with an artificial flood improves river habitats downstream of a dam. Scientific Reports, 9(1), 5176. https://doi.org/10.1038/s41598-019-41575-6

Swenson, J. B. (2005). Relative importance of fluvial input and wave energy in controlling the timescale for distributary-channel avulsion. Geophysical Research Letters, 32, L23404. https://doi.org/10.1029/2005GL024758

Swenson, J. B., Paola, C., Pratson, L., Voller, V. R., \& Murray, A. B. (2005). Fluvial and marine controls on combined subaerial and subaqueous delta progradation: Morphodynamic modeling of compound-clinoform development. Journal of Geophysical Research, 110, F02013. https://doi.org/10.1029/2004JF000265

Syvitski, J. P. M., \& Saito, Y. (2007). Morphodynamics of deltas under the influence of humans. Global and Planetary Change, 57(3-4), 261-282. https://doi.org/10.1016/j.gloplacha.2006.12.001

Wang, J., Muto, T., Urata, K., Sato, T., \& Naruse, H. (2019). Morphodynamics of river deltas in response to different basin water depths: An experimental examination of the grade index model. Geophysical Research Letters, 46, 5265-5273. https://doi.org/10.1029/2019GL082483

Wang, Z. B., Wang, Z. Y., \& de Vriend, H. J. (2008). Impact of water diversion on the morphological development of the lower Yellow River. International Journal of Sediment Research, 23(1), 13-27. https://doi.org/10.1016/S1001-6279(08)60002-5

Wang, Z. Y., \& Liang, Z. Y. (2000). Dynamic characteristics of the Yellow River mouth. Earth Surface Processes and Landforms, 25(7), 765-782. https://doi.org/10.1002/1096-9837(200007)25:7<765::AID-ESP98>3.0.CO;2-K

Wohl, E., Bledsoe, B. P., Jacobson, R. B., Poff, N. L., Rathburn, S. L., Walters, D. M., \& Wilcox, A. C. (2015). The natural sediment regime in rivers: Broadening the foundation for ecosystem management. Bioscience, 65(4), 358-371. https://doi.org/10.1093/biosci/biv002

Wu, C., \& Nittrouer, J. A. (2020). Impacts of backwater hydrodynamics on fluvial-deltaic stratigraphy. Basin Research, 32(3), 567-584. https://doi.org/10.1111/bre.12385

Wu, C., Nittrouer, J. A., Muto, T., Naito, K., \& Parker, G. (2020). Morphodynamic equilibrium of lowland river systems during autoretreat Geology. https://doi.org/10.1130/G47556.1

Zaprowski, B. J., Pazzaglia, F. J., \& Evenson, E. B. (2005). Climatic influences on profile concavity and river incision. Journal of Geophysical Research, 110, F03004. https://doi.org/10.1029/2004JF000138

Zheng, S., Edmonds, D. A., Wu, B., \& Han, S. (2019). Backwater controls on the evolution and avulsion of the Qingshuigou channel on the Yellow River Delta. Geomorphology, 333(15), 137-151. https://doi.org/10.1016/j.geomorph.2019.02.032 